University at Buffalo School of Law

Digital Commons @ University at Buffalo School of Law

\title{
Rethinking Equality and Difference: Disability Discrimination in Public Transportation
}

Martha T. McCluskey

University at Buffalo School of Law

Follow this and additional works at: https://digitalcommons.law.buffalo.edu/journal_articles

Part of the Civil Rights and Discrimination Commons

\section{Recommended Citation}

Martha T. McCluskey, Rethinking Equality and Difference: Disability Discrimination in Public

Transportation, 97 Yale L.J. 863 (1988).

Available at: https://digitalcommons.law.buffalo.edu/journal_articles/528

\section{C) ${ }_{\text {COPYRIGHT }}^{\text {N }}$}

This Article is brought to you for free and open access by the Faculty Scholarship at Digital Commons @ University at Buffalo School of Law. It has been accepted for inclusion in Journal Articles by an authorized administrator of Digital Commons @ University at Buffalo School of Law. For more information, please contact lawscholar@buffalo.edu. 


\title{
Rethinking Equality and Difference: Disability Discrimination in Public Transportation
}

\author{
Martha T. McCluskey
}

People with physical disabilities ${ }^{\mathbf{1}}$ in the United States have faced, and continue to struggle against, many social and economic disadvantages. Over the years, laws have explicitly excluded people with disabilities from holding public office, ${ }^{2}$ serving on juries, ${ }^{3}$ marrying, ${ }^{4}$ working in certain occupations, ${ }^{6}$ bearing children, ${ }^{6}$ attending school, ${ }^{7}$ and even from being seen on public streets. ${ }^{8}$ Even today, people with disabilities are "substan-

1. This Note will use the term "disability" in place of "handicap." Although there is disagreement about which term is preferable, many people believe "handicap" carries connotations of inferior status. The phrase "people with disabilities" in place of "disabled people" or "the disabled" emphasizes that people should not be reduced to their disabilities. See National Easter Seal Soc'y, Portraying People with Disabilities in the Media $\S 1$ (undated).

This Note uses "disability" to include all physical disabilities covered by $\S 504$ of the Rehabilitation Act of 1973. See 29 U.S.C.A. $\$ 706(8)$ (B) (West Supp. 1988). Section 504 covers any person who has, is regarded as having, or has a record of having a physical or mental impairment which substantially limits one or more of that person's major life activities. Id. Some examples of disabilities included in this definition are hearing impairments, epilepsy, visual impairments, and neuromotor impairments.

The discussion in this Note will be limited to physical disabilities, since the issue of equality for people with mental disabilities may raise somewhat different questions. For a discussion of equality in the context of mental disability, see Comment, We Have Met the Imbeciles and They Are Us: The Courts and Citizens With Mental Retardation, 65 NEB. L. REv. 768 (1986).

2. See, e.g., State ex rel. Shea v. Cocking, 66 Mont. 169, 213 P. 594 (1923) (overturning city's disqualification of judge for blindness).

3. See, e.g., Kaiser, Juries, Blindness, and the Juror Function, 60 CHI. KENT L. Rev. 191 (1984) (professor, excluded from jury service because of his blindness, arguing against excluding people who are blind from jury service).

4. At least 17 states have prohibited persons with epilepsy from marrying. Burgdorf \& Burgdorf, A History of Unequal Treatment: The Qualifications of Handicapped Persons as a "Suspect Class" Under the Equal Protection Clause, 15 SANTA Cl.ARA LAw. 855, 861 (1975) (citing Perr, Epilepsy and the Law, 7 Clev.-Marshall L. Rev. 280, 289 (1958)).

5. See, e.g., King-Smith v. Aaron, 317 F. Supp. 164 (W.D. Pa. 1970), rev'd, 455 F.2d 378 (3d Cir. 1972) (dismissing claims of teacher denied eligibility for employment in public schools by state statute because of her blindness).

6. As recently as 1980 , four states (Delaware, Mississippi, Oklahoma, and South Carolina) had statutes authorizing the sterilization of persons with epilepsy. Developments in the Law-The Constitution and the Family: Procreative Rights 93 HARv. L. REv. 1296, 1297 \& n.13 (1980).

7. In 1975, Congress found that one million children with disabilities were excluded from the public school system. U.S. Comm'N on Givil Rights, Clearinghouse Pub. No. 81, AccommoDating the Spectrum of Individual AbILrTies 27 (1983) (citing 20 U.S.C. $§ 1400(b)(4)$ (1982)) (finding is part of statute).

8. A Chicago ordinance prohibited persons who were "diseased" or "deformed" so as to be "unsightly or disgusting object[s]" from exposing themselves to public view on streets or in other public places. Chicago, ILL., Mun. Code $\S 36-34$ (1966) (repealed 1973), quoted in Burgdorf \& Burgdorf, 
tially worse off on almost any indicator of well-being [including education, employment, and earnings] than are the non-disabled." One survey found that $50 \%$ of people with disabilities aged sixteen and over had household incomes for 1984 of $\$ 15,000$ or less, compared to $25 \%$ of nondisabled people. $^{10}$

To alleviate some of the problems confronted by people with disabilities, Congress enacted section 504 of the Rehabilitation Act of 1973, which prohibits discrimination on the basis of disability in federally funded programs. ${ }^{11}$ Congress modeled section 504 on civil rights legislation that prohibits race and sex discrimination. ${ }^{12}$

Despite the similarity of section 504 to race and sex discrimination legislation, and despite the similar problems addressed by these laws, courts and lawmakers interpreting section 504 have often departed from the race and sex discrimination model. In contrast to race and sex discrimination doctrine, disability discrimination law generally assumes that physical difference, not prejudice, is the primary problem. This Note argues, however, that prejudice is central to the problems faced by people with disabilities. The failure to recognize this prejudice leaves disability discrimination doctrine confused and inadequate.

This Note will focus on federal nondiscrimination regulations governing public transportation as an example of the problems with current disability discrimination doctrine. Public transportation has been a major target of the reform efforts of disability rights groups. ${ }^{13}$ Access to public

supra note 4, at 863-64 (also referring to similar statutes in Columbus, Ohio and Omaha, Neb.).

9. R. Burkhauser \& R. Haveman, United States Policy Toward the Disabled and EMPloyment Handicapped 15 (International Institute of Management/Labor Market Policy Discussion Paper No. 84-4a, 1984).

10. Louis Harris \& Assocs., Inc., Study No. 854009, The ICD Survey of Disabled Americans: Bringing Disabled Americans into the Mainstream 23 (1986). People of color who have disabilities are particularly likely to have incomes below the poverty line. B. WolfE, IMpacts of Disability and Some Policy Implicatrons 26 (Wisconsin University Institute for Research on Poverty Discussion Paper No. 539, 1979).

11. 29 U.S.C.A. $\$ 794$ (West Supp. 1988), as amended by Civil Rights Restoration Act of 1987 , Pub. L. No. 100-259, 56 U.S.L.W. 45 (1988). Section 504 states: "No otherwise qualified individual with handicaps . . . shall, solely by reason of his handicap, be excluded from the participation in, be denied the benefits of, or be subjected to discrimination under any program or activity receiving Federal financial assistance...."Id.

12. S. Rep. No. 1297, 93d Cong., 2d Sess., reprinted in 1974 U.S. Code Cong. \& Admin. News 6373, 6390. The language is similar to title VI of the Civil Rights Act of 1964, which provides that "[n]o person in the United States shall, on the ground of race, color, or national origin, be excluded from participation in, be denied the benefits of, or be subjected to discrimination under any program or activity receiving Federal financial assistance." 42 U.S.C. $\S 2000 \mathrm{~d}$ (1982), as amended by Givil Rights Restoration Act of 1987, Pub. L. No. 100-259, 56 U.S.L.W. 46 (1988).

No federal statute prohibits disability discrimination by private employers who do not receive fedcral funds or contracts. Disability is not included in title VII, which prohibits discrimination in private employment on the basis of race, sex, color, national origin, or religion. See 42 U.S.C. $\$ \$ 2000 \mathrm{e}$ $-2000 \mathrm{e}-17$ (1982).

13. For a discussion of litigation concerning access to public transportation, see R. KATZMANN, Institutional Disability: The Saga of Transportation Policy for the Disabled 155-85 (1986). Transportation has also been the focus of much protest activity. See, e.g., Wheelchair Warriors, TIME. Oct. 12, 1987, at 33 (protesters arrested at transit agency convention). 
transportation is crucial for assuring access to employment, political activity, education, shopping, and recreation. Moreover, this is an area where frequent changes in the law have heightened the questions concerning the meaning of equality in the disability context. ${ }^{14}$

Section I of this Note will show how the emphasis on difference instead of prejudice has shaped disability discrimination doctrine. This Section will then draw on insights from sex discrimination theory to demonstrate that pervasive prejudice against people with disabilities exists even though it may be difficult to recognize, and that perceptions about difference are socially constructed and influenced by this prejudice. Section II will argue that biased assumptions concerning difference have resulted in the development of inadequate public transportation regulations under section 504 . Finally, Section III will suggest that disability discrimination doctrine would be strengthened by adhering more closely to the disparate impact model, which can remedy the subtle prejudice that makes the "differences" of disability so disadvantageous.

\section{Addressing Difference Within Equality Doctrine}

\section{A. Separating Prejudice from Difference}

Traditional legal approaches to achieving equality have aimed at eliminating prejudice. The equal treatment principle, incorporated in race and sex discrimination doctrine, holds that "similarly situated" people must be treated alike. ${ }^{15}$ Courts and Congress recognize that widespread prejudice against racial minorities and women often causes irrational and harmful perceptions of differences between groups that are actually "similarly situated" for most legitimate purposes. ${ }^{16}$ In current doctrine, real race differences, such as skin color, are almost always irrelevant to any legitimate purpose. ${ }^{17}$ Courts similarly believe that differentiation based on sex is usually based on prejudice; in comparison to the race context, however, courts are more likely to believe that real sex differences, such as preg-

People with disabilities who have difficulty using public transportation are present in one out of eight households in the urban United States. Grey ADVfr'IIsing, Summary Report of Data From National Survey of Transportation Handicapprid Propi.e 16 (1978) (Report for Department of Transportation).

14. See infra Section II-A.

15. See City of Cleburne v. Cleburne Living Center, Inc., 473 U.S. 432, 439 (1985) (equal protection clause essentially directs "that all persons similarly situated should be treated alike") (citation omitted).

16. "Classifying persons according to their race is more likely to reflect racial prejudice than legitimate public concerns . . . " Palmore v. Sidoti, 466 U.S. 429, 432 (1984) (citation omitted) (overturning state court's denial of custody of child to mother based on her interracial marriage).

17. "A racial classification, regardless of purported motivation, is presumptively invalid and can be upheld only upon an extraordinary justification." Personnel Adm'r v. Feeney, 442 U.S. 256, 272 (1979) (citations omitted). 
nancy, sometimes provide legitimate reasons to distinguish between people. ${ }^{18}$

To discourage differentiation based on prejudice, unequal treatment on the basis of race or sex is prohibited by federal statutes ${ }^{10}$ and is subject to heightened scrutiny under the equal protection clause. ${ }^{20}$ In addition to the equal treatment doctrine, courts have interpreted some statutes prohibiting race and sex discrimination to incorporate a disparate impact approach to discrimination. ${ }^{21}$ This doctrine prohibits not just explicitly unequal treatment, but also facially neutral treatment that has unnecessary unequal effects. ${ }^{22}$ Like the equal treatment principle, disparate impact is designed to eliminate differentiation based on prejudice, but disparate impact goes beyond equal treatment to reach subtle forms of prejudice and the effects of past unequal treatment. ${ }^{23}$

In contrast to both the race and sex contexts, most courts and commentators perceive that the real physical differences related to disability are frequently relevant to the ability to function in society, and that real differences, not false, prejudice-based perceptions of difference, are therefore the primary cause of the relative disadvantages of people with disabilities. ${ }^{24}$ Most agree that if section 504 simply required equal treatment of

18. In constitutional equal protection claims, sex-based classifications are less suspect than racebased classifications. See infra note 20 . The Supreme Court "has consistently upheld statutes where the gender classification is not invidious, but rather realistically reflects the fact that the sexes are not similarly situated in certain circumstances." Michael M. v. Superior Court, 450 U.S. 464, 469 (1981) (citations omitted) (upholding gender-based statutory rape law).

19. See International Bhd. of Teamsters v. United States, 431 U.S. 324,335 n.15 (1977) (title VII prohibits disparate treatment, which occurs when some people are treated less favorably than others because of their race, color, religion, sex, or national origin).

20. See U.S. CoNST. amend. XIV, \&1. Classifications based on race violate the equal protection clause unless they are necessary to the accomplishment of a compelling and legitimate government interest. Palmore v. Sidoti, 466 U.S. at 432-33. Gender classifications must be substantially related to an important government objective. Craig v. Boren, 429 U.S. 190, 197 (1976). The Supreme Court has not decided whether classifications based on physical disability deserve heightened scrutiny under the equal protection clause, although it has ruled that classifications based on mental retardation do not. See City of Cleburne v. Cleburne Living Center, Inc., 473 U.S. 432 (1985).

21. Courts developed the disparate impact doctrine to interpret title VII of the Civil Rights Act of 1964. See Griggs v. Duke Power Co., 401 U.S. 424 (1971). Disparate impact doctrine has been used under other nondiscrimination statutes, including title VI, the model for $\S 504$. See Guardians Ass'n v. Civil Serv. Comm'n, 463 U.S. 582 (1983) (plurality) (regulations implementing title VI can prohibit disparate impact discrimination). The Supreme Court has rejected the disparate impact approach for equal protection claims. Washington v. Davis, 426 U.S. 229 (1976).

22. To make a disparate impact claim, a plaintiff must first demonstrate that a policy or practice has a disparate effect on a protected group compared to other groups. The defendant then must prove that the policy is necessary or manifestly related to a legitimate interest. Finally, if the defendant meets this burden, the plaintiff must then prove that alternative policies, without the adverse effect, will adequately serve the same business interest. See Dothard v. Rawlinson, 433 U.S. 321, 329 (1977).

23. See Fiss, A Theory of Fair Employment Laws, 38 U. CHI. L. Rev. 235, 299 (1971) (one justification for prohibiting facially neutral criteria with harmful differential effects on blacks is that these criteria may often be the functional equivalent of race); Rebell, Structural Discrimination and the Rights of the Disabled, 74 GEo. L.J. 1435, 1450 (1986) (in race discrimination context, disparate impact analysis helps overcome effects of decades of intentional discrimination).

24. For example, the Supreme Court has said that sex, like race, differs from physical disability because sex is a characteristic that "frequently bears no relation to ability to perform or contribute to 
people with disabilities and nondisabled people, it would fail to address the particular disadvantages faced by people with disabilities. ${ }^{25}$ For example, the predominant view is that equal access to public transportation does not simply mean giving people who use wheelchairs equal opportunity to use the stairs on a bus. Accordingly, courts have generally adopted a "reasonable accommodation" approach to section 504. ${ }^{26}$ Reasonable accommodation goes beyond a simple equal treatment principle to require changes in some practices and structures to alleviate the disadvantageous effects of physical differences, but does not require accommodations that impose "undue administrative and financial burdens" or that would require a "fundamental alteration in the nature of [a] program."27

Yet the question of how much accommodation section 504 requires remains subject to conflict and confusion. ${ }^{28}$ This Note advocates the approach adopted by a few decisionmakers who have interpreted section 504, following the disparate impact model from race and sex discrimination law, to require, in general, a goal of integrated, equally effective programs for people with disabilities and nondisabled people. ${ }^{29}$

Many courts, policymakers and commentators, however, are reluctant to take section 504 that far. In their view, less effective programs are often a "neutral" result of physical limitations, not prejudice or its effects, and therefore the disparate impact model's presumption against unequal effects must be limited in order to avoid interfering with legitimate inter-

society." Frontiero v. Richardson, 411 U.S. 677, 686 (1973) (plurality) (dictum) (footnote omitted); see also Rebell, supra note 23, at 1456, 1452 (claiming there has been no history of de jure discrimination or animus against people with disabilities comparable to that in race discrimination; instead, major problems come from lack of awareness or from "neutral" barriers); Wegner, The Antidiscrimination Model Reconsidered: Ensuring Equal Opportunity Without Respect to Handicap Under Section 504 of the Rehabilitation Act of 1973, 69 CoRNELL L. REv. 401, 429 (1984) (denial of equal opportunity on the basis of disability often has legitimate factual basis, instead of being motivated by ill will); Note, Employment Discrimination Against the Handicapped and Section 504 of the Rehabilitation Act: An Essay on Legal Evasiveness, 97 HARv. L. REv. 997, 1001 (1984) (Although some employment barriers are similar to those faced by other minority groups, "[s]ubstantial physical or mental impairments . . . present disabled persons with a more intractable set of problems.") (footnotes omitted).

Section 504 limits its coverage to those who are "otherwise qualified," suggesting a concern that disability may often be relevant to legitimate program criteria. Compare 29 U.S.C.A. $\$ 794$ (West Supp. 1988), as amended by Civil Rights Restoration Act of 1987, Pub. L. No. 100-259, 56 U.S.L.W. 45 (1988) ( $\$$ 504) with 42 U.S.C. $\S 2000 \mathrm{~d}$ (1982), as amended by Civil Rights Restoration Act of 1987, Pub. L. No. 100-259, 56 U.S.L.W. 46 (1988) (title VI). See supra notes 11-12.

25. Courts have generally agreed that $\S 504$ prohibits some unequal effects, not merely unequal treatment. See Alexander v. Choate, 469 U.S. 287, 297 n.17 (1985).

26. "Reasonable accommodation" is also required by laws prohibiting discrimination based on religion. See title VII of the Civil Rights Act of 1964, 42 U.S.C. § 2000e(j) (1982).

27. School Bd. v. Arline, 107 S. Ct. 1123, 1131 n.17 (1987) (dictum, discussing employment) (quoting Southeastern Community College v. Davis, 442 U.S. 397, 410, 412 (1979)). Courts sometimes use the term "disparate impact" in conjunction with reasonable accommodation by considering whether $\$ 504$ requires accommodations to eliminate adverse impacts. See, e.g., Alexander v. Choate, 469 U.S. at 299 , discussed infra notes 84-87 and accompanying text. Nevertheless, this use of "disparate impact" often differs from the race and sex contexts. See infra text accompanying notes 29-32.

28. See infra Section II-A (discussing frequent changes in disability discrimination doctrine concerning public transportation); Rebell, supra note 23 , at 1441.

29. See, e.g., infra notes 69-73 and accompanying text. 
ests. $^{30}$ Some advocate balancing the interests of people with disabilities against other interests, rather than presuming unequal effects to be unlawful. ${ }^{31}$ Others take the view that differences make separate programs an acceptable means of accommodating people with disabilities. ${ }^{32}$ This Note, however, argues that this trend in disability discrimination doctrine is based on flawed assumptions about the problem of difference, and that a reexamination of these assumptions will show that an approach based on the disparate impact model from race and sex discrimination doctrine is preferable.

\section{B. Feminist Analysis: Uncovering Prejudice}

Just as courts and commentators believe that prejudice plays a minor role in disability discrimination, they have often overlooked much of the prejudice against women. ${ }^{33}$ Feminists, however, have exposed many problems of prejudice against women that the legal system has largely ignored or condoned as natural, such as gender bias in the courts, sexual harassment in the workplace, and wife-battering. ${ }^{34}$ Insights from feminist scholarship can improve disability discrimination doctrine by revealing a pattern of prejudice masked by ideas about difference, a pattern that operates similarly in both sex discrimination and disability discrimination. ${ }^{36}$

Feminist theorists have argued that the existence of pervasive prejudice

30. See Wegner, supra note 24 , at 514 (facially neutral policies that provide unequal benefits to people with disabilities, but do not totally deny access to programs, are often based on legitimate decisions more appropriate to legislative bodies than to courts); Rebell, supra note 23, at 1451-52 ("Without some intentionally discriminatory acts to provide a basis for ultimate liability, some further justification is required to establish why an 'innocent' defendant should be put to the trouble or expense of changing practices which 'happen' to cause difficulties for the handicapped."); infra notes 84-87 and accompanying text.

31. For example, Attorney Michael Rebell proposes a new "structural accommodation" approach which essentially involves balancing the needs of people with disabilities against other interests such as resource limitations, along with setting certain priority areas to guide the balancing process. See Rebell, supra note 23, at 1455-56. Rebell's structural discrimination approach would probably not change the outcomes of particular disability discrimination cases recently decided by the Supreme Court, but would avoid what he perceives as confusing and unprincipled reasoning based on race discrimination approaches designed for eliminating prejudice. See id. at 1441-52, 1464-70.

32. See, e.g., infra text accompanying notes 93-95 (regulations permitting segregated public transportation).

33. For example, Professor John Hart Ely claims that hostility against women is rare. J. ELY, DEMOCRACY AND DISTRUST 164 (1980). " 'Some of my best friends are Negro" got to be a parody of white hypocrisy, but the best friend of most men really is a woman, which eliminates the real hostility and fear that persists among the races." Id. at 257 n.94 (emphasis in original).

34. See, e.g., State v. Hundley, 236 Kan. 461, 467, 693 P.2d 475, 479 (1985) ("[T]raditional attitudes have made legal and actual recognition of wife beating's criminal nature slow in coming."). See generally C. Mackinnon, Sexual Harassment of Working Women (1979) (arguing that sexual harassment has been systematically ignored and instead should be recognized as sex discrimination). Bias against women in the courts has only recently been examined. See The First Year Report of the New Jersey Supreme Court Task Force on Women in the Courts-June 1984, 9 WoMEN's RTS. L. REP. 129, 134 (1986). In a 1983 survey of New Jersey attorneys, $69 \%$ of women and $40 \%$ of men reported hearing judges make sexist jokes and remarks hostile to women. Id. at 140. Many attorneys in the survey thought such behavior influenced the litigation process, and some believed it affected outcomes of cases. Id. at 141.

35. See infra Section I-C. 
against women has often made recognizing that prejudice difficult. The more prejudice is routine, the more what is defined as normal and rational is really prejudice. ${ }^{36}$ Professor Ann Scales contends that in sex discrimination doctrine, "the 'relevant' differences have been and always will be those which keep women in their place." ${ }^{37}$ Much of what claims to be objective or neutral instead expresses a point of view that ignores the perspectives of groups subjected to systematic prejudice. ${ }^{38}$

Prejudice against people with disabilities may similarly be overlooked or minimized by those not subjected to it. Given the extensive structure of laws that have enforced the exclusion of people with disabilities from many areas of society, ${ }^{39}$ it is not surprising that prejudice against people with disabilities is often invisible to many people.

Nevertheless, examples of prejudice abound, as in the race and sex discrimination contexts. ${ }^{10}$ For example, a writer who has a disability describes an example of the prejudice that he has encountered: "I was sitting on a corner several years ago when a carload of teens went by. One kid yelled out the window, 'Hey, look at that cripple, you guys!' 'Whatsa matter-can't ya walk?' another shouted. And they sped away laughing."1 A professor who has quadriplegia said, "I have been served meals in separate dining areas of restaurants since, as the owners were quick to point out, I might upset the other customers and lessen their enjoyment of the meal." $" 12$

In addition to overt expressions of hostility, prejudice in the disability context often takes the form of fear, avoidance or pity. ${ }^{43}$ But these attitudes still serve to deny another's humanity and to assert one's own superiority. Denial or fear of one's own potential disability may increase the tendency to scapegoat people with disabilities. "The disabled, then, serve

36. See MacKinnon, Feminism, Marxism, Method, and the State: Toward Feminist Jurisprudence, 8 Signs: J. WOMEN IN Culture \& Soc'y 635, 654 (1983).

37. Scales, The Emergence of Feminist Jurisprudence: An Essay, 95 YALE L.J. 1373, 1378 (1986) (footnote omitted).

38. See id. at 1377 (maleness has been made the norm in the name of neutrality); Minow, The Supreme Court, 1986 Term-Foreword: Justice Engendered, 101 HARv. L. REv. 10, 68 (1987) ("Power is at its peak when it is least visible, when it shapes preferences, arranges agendas, and excludes serious challenges from discussion or even imagination.") (footnote omitted).

39. See supra notes 2-8 and accompanying text.

40. For a comparison of prejudice faced by blacks and people with disabilities, see Kriegel, Uncle Tom and Tiny Tim: Some Reflections on the Cripple as Negro, 38 AM. SCHOLAR 412, 416 (1969) (both blacks and people with disabilities face society that is uncomfortable with them, and both groups must struggle for positive identity). Forty-five percent of people with disabilities in the U.S. feel they are a minority group in the same sense as are blacks and Hispanics. Louis Harris \& Assoc., INC., supra note 10 , at 112 .

41. Hooper, The Dignity Thief, Disabilrty RaG, Jan./Feb. 1988, at 18.

42. Hillam, You Gave Us Your Dimes. . ., NewsweEk, Nov. 1, 1976, at 13, quoted in Gittler, Fair Employment and the Handicapped: A Legal Perspective, 27 DePaul L. Rev., 953, 969 n.52 (1978).

43. Like open hostility, these more subtle forms of prejudice are likely to encourage designs of public programs that keep people with disabilities separate and disadvantaged.

44. See F. Bowe, Handicapping America: Barriers to Disabled People 118-19 (1978); S. Kleinfield, The Hidden Minority 182-83 (1977). 
a useful function in society, making 'normal' persons feel healthier, brighter, more competent, and secure."45

Psychologists studying attitudes toward people with disabilities report widespread prejudice. ${ }^{46}$ "Studies show that only a bit more than half of the population of the United States expresses slightly positive attitudes toward the disabled. The rest openly admit to negative attitudes. They see the handicapped as different and in some ways inferior to normal people."'47

Cultural images often reflect this prejudice by excluding or devaluing people with disabilities. ${ }^{48}$ "Not only are disabled characters in fiction [for example, Captain Hook and Captain Ahab] set apart from others but they are often cast as villains plotting demented revenge against pristine heroes or heroines. Physical beauty, in these stories, symbolizes goodness, disability evil." 49 This evidence of pervasive prejudice against people with disabilities invalidates the assumption that physical differences are the primary cause of disability discrimination. Instead, this widespread prejudice has become deeply embedded in "normal" social institutions and concepts, including traditional ideas about physical differences.

\section{Rethinking Difference: Critique of the Male Norm Applied to the Able-bodied Norm}

Like disability discrimination theory, sex discrimination theory has struggled with the issue of how to deal with physical differences. Some theorists advocate a "special treatment" approach to sex differences. ${ }^{50}$ The special treatment approach is similar to "reasonable accommodation" in

45. Eisenberg, Disability as Stigma, in Disabled People as Second-Class Crtizens 5 (M. Eisenberg, C. Griggins \& R. Duval eds. 1982).

46. One study showed that a visible disability had a greater negative influence than racial differences on children's preferences for other children. Richardson \& Royce, Race and Physical Handicap in Children's Preference for Other Children, 39 CHILD Dev. 467 (1968), cited in SafiliosRothschild, Social and Psychological Parameters of Friendship and Intimacy for Disabled People, in Disabled People as Second-Class Crtizens, supra note 45, at 43.

47. S. Kl.Einfifid, supra note 44, at 173 (quoting Harold Yuker, Professor of Psychology at Hofstra University).

48. See Kriegel, supra note 40 , at 426 (society values an occasionally bizarre sense of physical beauty unattainable by people with disabilities); A. JAGgar, FEmINIST Politics and Human NATURE 40-48 (1983) (criticizing predominant western philosophical image of humans as independent, rational beings free from biological needs).

49. F. Bowe, supra note 44 , at 109 . Some seemingly positive images also express harmful stereotypes. Famous people with disabilities, such as Helen Keller, are often portrayed in an unrealistic way that suggests that all people with disabilities are superhuman beings who are expected to "overcome" their disabilities. See id. at 111. Fundraising telethons featuring children with disabilities can perpetuate stereotypes of people with disabilities as childlike and dependent on charity. See id. at 110 .

50. See, e.g., Krieger \& Cooney, The Miller-Wohl Controversy: Equal Treatment, Positive Action and the Meaning of Women's Equality, 13 GoLDEN GATE U.L. REv. 513 (1983) (supporting state statute giving women special treatment by requiring job security for women unable to work because of pregnancy-related disability); Law, Rethinking Sex and the Constitution, 132 U. PA. L. REV. 955 (1984) (arguing that sex discrimination doctrine should depart from equal treatment approach in analyzing laws governing women's reproductive biology). 
its assumption that at least some of women's disadvantages relative to men stem not from prejudice, but from sex differences, such as women's ability to become pregnant. ${ }^{51}$ Special treatment advocates argue that equality for women requires some different treatment (pregnancy leave, for example) in recognition of real sex differences, not simply equal treatment of men and women. ${ }^{62}$

Other feminist theorists argue, however, that instead of attempting to distinguish real from stereotypical differences, equality doctrine should challenge the male-biased norms that make difference, including physical differences, a problem for women..$^{33}$ As Professor Martha Minow has observed, biased standards are at the source of the confusion about how equality doctrine should deal with the differences of disability as well as gender. ${ }^{\mathrm{st}}$

Professor Catharine MacKinnon criticizes traditional equality doctrine for giving women a choice of either being like men with the equal treatment approach or different from men with special treatment. ${ }^{\text {s5 }}$ Either way, women lose because men are the standard against which women are measured ${ }^{s B}$ Ending gender inequality requires eliminating this male standard underlying both equal treatment and special treatment. Professor Wendy Williams argues that pregnancy does not create "special" needs requiring different treatment, but rather exemplifies basic human needs. ${ }^{57}$

Similarly, in terming the physical needs of people with disabilities "different," "special," and in need of "accommodation," society implies that able-bodied people are the norm, and that people with disabilities are the deviations. ${ }^{58}$ Able-bodied people are not considered "different."

51. In fact, special treatment advocates have claimed that the reasonable accommodation approach to disability discrimination is a model of a successful special treatment approach to equality. See Krieger \& Cooney, supra note 50, at 559-60; Note, Sexual Equality Under the Pregnancy Discrimination Act, 83 Colum. L. REv. 690, 717-18 (1983). In contrast, critics of special treatment argue that reasonable accommodation is not a good model for sex discrimination doctrine because it is an approach that has required only limited changes. See Taub \& Williams, Will Equality Require More than Assimilation, Accommodation or Separation from the Existing Social Structure?, 37 RUTGERS L. REv. 825, 833-34 (1985).

52. See Krieger \& Cooney, supra note 50. Critics of special treatment fear that any different treatment of women may reinforce harmful stereotypes of women. See, e.g., Williams, Equality's Riddle: Pregnancy and the Equal Treatment/Special Treatment Debate, 13 N.Y.U. REv. L. \& Soc. Change 325 (1984-85).

53. See C. Mackinnon, Feminism Unmodified: Discourses on Life and Law 32-45 (1987); Finley, Transcending Equality Theory: A Way Out of the Maternity and the Workplace Debate, 86 Colum. L. Rev. 1118, 1152-59 (1986); Scales, supra note 37, at 1380-83; Taub \& Williams, supra note 51 , at 834-36.

54. See Minow, supra note 38, at 31-57.

55. C. MACKINNON, supra note 53 , at 33 .

56. See id. at 34 .

57. Williams, supra note 52 , at 327 .

58. See Taub \& Williams, supra note 51, at 834; Minow, supra note 38 , at 32

59. "[T]he very claim to knowledge manifested by the labeling of any group as different ... disguises the act of power by which the namers simultaneously assign names and deny their relation. ships with, and power over, the named." Minow, When Difference Has Its Home: Group Homes for the Mentally Retarded, Equal Protection and Legal Treatment of Difference, 22 HaRv. C.R.-C.L. 
This view fails to recognize that disability is normal. The needs of people with disabilities, such as the need for ramps instead of stairs, are basic human needs shared by large numbers of people. ${ }^{60}$ All people have physical limitations, and all can expect to have more disabilities as they grow older. The labels "able-bodied" and "disabled" only approximate the wide range of human physical activity. Most people are "disabled" compared to professional athletes or opera singers. ${ }^{61}$ An able-bodied norm is incorrect not only because it implies that disability is unusual, but because it also suggests that disability is inherently deviant and abnormal in a normative sense. ${ }^{62}$ Disability, however, is not a characteristic that should stigmatize a person or detract from her value as a human being. ${ }^{63}$

It is common to think of the problems of disability, like the problems of pregnancy, as caused purely by physiology. For example, if a wheelchair user cannot get up the stairs of a bus, that problem seems to be "caused" by her disability. Many people with disabilities argue, however, that they are burdened primarily by society, not by their disability. ${ }^{64} \mathrm{~A}$ society

L. REv. 111, 128 (1987).

60. A 1986 survey estimated that there were about 27 million people with disabilities over age 16 in the United States. See Louis HaRRIS \& Assoc., INC., supra note 10, at iii.

61. Garrity v. Gallen, 522 F. Supp. 171, 206 (D.N.H. 1981), quoted in U.S. CoMM'N ON GiviL RighTs, supra note 7 , at 89-90.

62. "[T]here is something inherent in the concept of a standard for assessment that views the standard as the norm, and everything that is dissimilar from the standard as the deviate 'other.' 'Different' and 'other' consequently have pejorative connotations . . . ." Finley, supra note 53, at 1153 (emphasis in original) (footnote omitted).

63. Although an able-bodied standard currently may seem objective and legitimate, this perception probably is influenced by bias. Traditionally, "maleness" and "whiteness" were similarly assumed to be objective standards for the most valued human traits. See, e.g., K. MiL.LETT, SEXuAl. Pol.rTics 258 n.66 (1969) (criticizing Freud, Aquinas, and Augustine for their views of women as imperfect men).

An able-bodied norm may seem appropriate in the sense that even in an ideal social environment, most individuals, given the choice, would probably choose not to have any particular disability. See Mairs, On Being a Cripple, in With Wings: An ANThology of Literature by and about Women with Disabilities 127 (M. Saxton \& F. Howe eds. 1987) ("[Having a disability] has opened and enriched my life enormously . . . . All the same, if a cure were found, would I take it? In a minute. . . . I'd take a cure; I just don't need one."). It does not follow, however, that people who do have disabilities are abnormal or inferior, or that laws and social structures should incorporate an able-bodied standard.

Special treatment advocates often fear that by requiring pregnancy to be treated the same as disabilities, laws such as the Pregnancy Discrimination Act, 42 U.S.C. $\$ 2000 \mathrm{e}(\mathrm{k})(1982)$, imply that pregnancy is abnormal and dysfunctional, not a normal phase in a women's life. See, e.g., Scales, Towards a Feminist Jurisprudence, 56 IND. L.J. 375, 429 (1981). A better approach would be to treat both pregnancy and disability as normal human events.

64. Most disabled people feel that the disability itself, the pain, the need for compensatory devices and assistance can produce considerable inconvenience, but that very often these become minimal or are forgotten once the individual makes the transition to everyday life. But the discriminatory attitudes and thoughtless behaviors, these are what make life difficult, these are the sources of the oppression.

Living in These Bodies, These Minds, in WITH Wings: AN ANThology of LITERATuRE By AND ABout WoMEN WITH DisabiLIties, supra note 63, at 3; see also Achtenberg, Law and the Physically Disabled: An Update with Constitutional Implications, 8 Sw. U.L. REv. 847, 848 (1976) ("More people are forced into limited lives and made to suffer by these man-made obstacles than by any specific physical or mental disability.") (footnote omitted); tenBroek, The Right to Live in the World: The Disabled in the Law of Torts, 54 CALIF. L. REv. 841, 842 (1966) (public attitudes play greater role than physical limitations in determining access of people with disabilities to public 
where childbearing women were considered typical workers would have workplace policies and social structures that would prevent pregnancy from impairing a woman's ability to work. ${ }^{66}$ Similarly, a society where people who have trouble climbing stairs were considered part of the group of typical transportation users might design buses with ramps and low floors as a matter of course. ${ }^{66}$ In such a society, a physical inability to climb stairs would not be a disadvantage to a person seeking access to public transportation.

\section{Regulations Governing Disability Discrimination in Public Transportation}

\section{A. Conflicting Views of Equality in Previous Regulations}

The federal regulations implementing section 504 in public transportation show a history of frequent changes, documenting the controversy about the meaning of disability discrimination. The first Department of Transportation (DOT) regulations implementing section 504, issued in 1976 , treat the transportation needs of people with disabilities as a largely optional and extra task. ${ }^{67}$ These rules required local transit agencies receiving federal funds to make "special efforts" to serve people with disabilities, but to a great extent the rules let local transit agencies decide the specific form and extent of these "special efforts."

In 1979, DOT replaced these regulations with new rules. ${ }^{68}$ Instead of

places); Shut In, Shut Out, Shut Up-Surviving the System, in WITH THE POWER OF EACH BREATH: A Disabled Women's Anthology 13 (S. Browne, D. Connors \& N. Stern eds. 1985) ("We are disabled more by barriers of access than from the specific conditions of our body.").

65. See Williams, supra note 52 , at 364.

66. "Side-walk curbs are not neutral or natural, but humanly constructed, obstacles." Minow, supra note 38 , at 14 n.19.

Technology is one social factor that shapes the effect of physical differences. Contraception and safe, legal abortion have changed the effects of women's reproductive differences. Similarly, new designs for wheelchairs, lifts, and buses can give wheelchair users greater mobility. In the past, DOT transportation engineers and planners commonly viewed the problems of people with disabilities as social service concerns outside their domain. R. KATZMANN, supra note 13, at 89 . These attitudes undoubtedly contributed to the lack of research on making buses accessible to people using wheelchairs.

67. See Urban Transportation Programing for Elderly and Handicapped Persons, 41 Fed. Reg. 18,234 (1976). These rules and subsequent DOT rules were issued pursuant to the Urban Mass Transportation Assistance Act of 1970, 49 U.S.C. app. $\$ 1612($ a) (1982), and the Federal-Aid Highway Act of 1973, 23 U.S.C. $\S 142$ note (1982), in addition to $\S 504$.

68. In an appendix, the regulations gave three examples of satisfactory "special efforts" with respect to people using wheelchairs: (1) spending a minimum proportion of federal aid on wheelchairaccessible service; (2) buying only wheelchair-accessible buses until one-half of the vehicles in the system were accessible, or providing a comparable substitute service for wheelchair users; (3) establishing a system of individual subsidies so that every wheelchair user could purchase ten round trips per week from any accessible service at prices equal to "regular fares." Urban Transportation Programing for Elderly and Handicapped Persons, 41 Fed. Reg. 18,234 (1976). These examples were simply illustrative, not mandatory minimum requirements. Id. Although these examples of "special efforts," if followed, would somewhat improve service for people with disabilities, they imply that providing transportation to people with disabilities is a special problem separate from "normal" transportation programs.

69. Nondiscrimination on the Basis of Handicap in Federally-Assisted Programs and Activities Receiving or Benefitting from Federal Financial Assistance, 44 Fed. Reg. 31,442 (1979). 
the "special efforts" approach, these new rules adopted an equal access approach, which incorporated the assumption that mass transit should normally be designed to meet the needs of both people with disabilities and nondisabled people. DOT made this change in response to rules issued in 1978 by the Department of Health, Education, and Welfare (HEW), which had authority to coordinate other agencies' implementation of section $504 .^{70}$ The HEW guidelines required federally funded programs to be accessible, as a whole, to people with disabilities. ${ }^{71}$

Following HEW's guidelines, DOT's 1979 rules required all new fixed route buses to be accessible to people with disabilities, including those using wheelchairs. ${ }^{72}$ Within three years, or ten years for modifying existing vehicles or facilities or making expensive structural changes, transit systems had to make at least one half of peak-hour bus service accessible. ${ }^{73}$

The equal access goal of the 1979 rules did not last long. In 1981, American Public Transit Association (APTA) v. Lewis ${ }^{74}$ held that a section of the rules governing specific requirements for mass transit was beyond the scope of DOT's authority under section 504 because it mandated expensive structural changes. ${ }^{75}$ The D.C. Circuit based its decision in this case on Southeastern Community College v. Davis, ${ }^{76}$ the Supreme Court's first decision interpreting section 504's substantive requirements. Davis upheld a nursing program's rejection of an applicant with impaired hearing, holding that section 504 does not require substantial modifications of programs to accommodate people with disabilities. ${ }^{77}$

APTA and Davis were incorrect, however, in characterizing substantial modifications for people with disabilities as burdensome affirmative steps

70. See Implementation of Executive Order 11,914, Nondiscrimination on the Basis of Handicap in Federally Assisted Programs, 43 Fed. Reg. 2132 (1978) (redesignated and currently codified, with amendments, at 28 C.F.R. $\$ 41$ (1987)). After the 1979 DOT rules were overturned (see infra text accompanying notes 74-75), the Department of Justice, which replaced HEW as the agency with coordinating authority for $\$ 504$, suspended the application of these guideline regulations to transportation. See Nondiscrimination on the Basis of Handicap in Federally Assisted Programs-Suspension of Guidelines with Respect to Mass Transportation, 46 Fed. Reg. 40,687 (1981).

71. The rules required new facilities to be readily accessible to people with disabilities, but did not necessarily require structural changes in existing facilities as long as the program "when viewed in its entirety is readily accessible to and usable by handicapped persons." 43 Fed. Reg. at 2138-39.

The HEW rules were influenced by HEW staff who used racial equality legislation as a madel, and also by substantial lobbying and protest activities, including the occupation of HEW Secretary Califano's office by disability rights organizations. See R. KatzManN, supra note 13, at 99-102.

72. See 44 Fed. Reg. at 31,478 .

73. Id.

74. 655 F.2d 1272 (D.C. Cir. 1981).

75. APTA admitted that $\S 504$ may require programs to make some accommodations for people with disabilities, but refused to interpret $\S 504$ to require costly accommodations. See id. at 1278 .

76. 442 U.S. 397 (1979).

77. See id. at 409-14. The Court did not define "substantial modification," but held that $\S 504$ does not require a fundamental alteration in the nature of a program, such as eliminating clinical courses for a nursing student. See id. at 409-10. The Court failed to recognize, however, that a program's traditional nature is likely to be shaped by able-bodied bias, see infra Section II-B, given society's tradition of exclusion and prejudice based on disability, see supra notes $2-10,40-49$ and accompanying text. 
outside the scope of a nondiscrimination requirement. ${ }^{78}$ Prejudice shapes the perception that the needs of people with disabilities are "extra" needs above and beyond the norm, and that meeting these needs is a form of preferential treatment. Instead, major changes may be necessary to correct the history of exclusion of people with disabilities from many benefits generally available to nondisabled people. ${ }^{79}$ For years, people with disabilities have paid taxes that have funded public transportation programs designed exclusively for nondisabled people. ${ }^{80}$ Professor MacKinnon describes American society as an affirmative action plan for white men; ${ }^{81}$ society could similarly be described as an affirmative action plan for ablebodied people. Without an understanding that inaccessible transportation is a matter of prejudice, not just natural differences, however, lawmakers are not likely to favor major changes such as those imposed by the 1979 rules.

As a result of APTA, DOT withdrew the challenged section of the 1979 regulations and substituted "interim final regulations" with requirements for bus systems similar to the vague "special efforts" rules of 1976. ${ }^{82}$ Taking the view that these rules would not result in enough access, Congress responded by passing a statute requiring DOT to promptly issue final rules that would establish clear minimum standards for accessible transportation service. ${ }^{83}$

Before DOT issued these final rules, the Supreme Court again considered the extent of accommodations required by section 504. In Alexander $v$. Choate ${ }^{84}$ the Court refused to limit section 504 to a simple equal treatment requirement, but left unanswered questions about when section 504 will forbid unequal effects. The Court assumed that section 504 may in some situations require accommodations to eliminate disparate impacts, ${ }^{85}$ but decided that policies with harmful effects on people with disabilities may be lawful if "meaningful and equal access" still exists. ${ }^{86}$ The court

78. See APTA, 655 F.2d at 1277; Davis, 442 U.S. at 410-13.

79. For some examples of this exclusion, see supra notes 2-8 and accompanying text.

80. Although many people with disabilities are not employed, a significant number have earned incomes and thus presumably have paid taxes. One 1978 study found that of the people with disabilities who have difficulty using public transportation, 1,141,000 are employed. GREY ADVERTISING, supra note 13 , at 18 .

81. C. MAcKinnon, supra note 53 , at 36 .

82. Nondiscrimination on the Basis of Handicap, 46 Fed. Reg. 37,488 (1981) (replacing 49 C.F.R. $\$ \S 27.81-.107$ (Subpart E) with a new section at 49 C.F.R. $\$ 27.77$ (Subpart D)).

83. See $\S 317$ (c) of the Surface Transportation Assistance Act of 1982, 49 U.S.C. app. $\S 1612$ (c) (1982); 128 CoNG. Rec. 30,825 (1982) (remarks of Sen. Cranston).

84. 469 U.S. 287 (1985) (reducing number of annual inpatient hospital days covered under state Medicaid program was not unlawful discrimination despite adverse effects on people with disabilities).

85. Id. at 299.

86. Id. at 302-06. Although the Court did not clearly define "meaningful and equal access," it explained that the Medicaid policy challenged in the case "is neutral on its face, is not alleged to rest on a discriminatory motive, and does not deny the handicapped access to or exclude them from the particular package of Medicaid services Tennessee has chosen to provide." Id. at 309. 
feared that "[b]ecause the handicapped typically are not similarly situated to the nonhandicapped," the disparate impact approach in some situations could lead to "a wholly unwieldy administrative and adjudicative burden." 87

Professor Minow notes, however, that fears about the unmanageability of considering "different" needs may stem from a biased perspective. ${ }^{88} \mathrm{~A}$ society that fails to consider the needs of people with disabilities will be unmanageable for people with disabilities. ${ }^{88}$ Considering effects of policies on people with disabilities should not be presumed more troublesome than considering effects of policies on nondisabled people.

\section{B. Able-Bodied Bias in the 1986 Regulations}

DOT issued final rules governing bus systems in $1986 .{ }^{\circ 0}$ In these rules, the able-bodied bias common throughout much of disability discrimination law persists. The rules imply that the general purpose of public transportation is to serve nondisabled people; service to people with disabilities is a special accommodation. For example, the rules describe inaccessible buses as buses serving the "general public." are "special service" vehicles. ${ }^{92}$

The 1986 rules give local transit agencies the choice of using a separate "special service" system or a mixed system as a substitute for making bus systems accessible. ${ }^{93} \mathrm{~A}$ majority of public comments to DOT from people with disabilities criticized the special service option on the ground that it would result in segregation and inferior service. ${ }^{94}$ Nevertheless, DOT de-

87. Id. at 298.

88. Minow, supra note 38 , at 52 .

89. See id.

90. Nondiscrimination on the Basis of Handicap in the Department of Transportation Financial Assistance Programs, 51 Fed. Reg. 18,994 (1986) [hereinafter DOT Rules] (codified at 49 C.F.R. $\S$ 27 (1987)). This Note's discussion of the 1986 DOT rules will focus on 49 C.F.R. $\$ \S 27.81-.103$ (Subpart E). The general provisions on program accessibility in Subpart C, which originally were part of the 1979 rules, were not at issue in APTA and remain in effect in the current rules, with some amendments. See 49 C.F.R. $\$ \S 27.61-.67$ (1987) (Subpart C, requiring programs in their entirety to be accessible). No court has yet decided the issue of the relationship between Subpart $E$ and Subpart C. Cf. Disabled in Action v. Sykes, 833 F.2d 1113 (3d Cir. 1987) (subway renovations must meet requirements in Subpart $\mathrm{G}$ in addition to those in Subpart $\mathrm{D})$.

91. See, e.g., 49 C.F.R. $§ 27.95$ (1987).

92. See 49 C.F.R. $₹ 27.95$ (b) (1987). This bias is similar to the inequality of the sex-segregated school system in Vorchheimer v. School Dist., 532 F.2d 880 (3d Cir. 1976), affd by equally divided court, 430 U.S. 703 (1977). The public high school for boys only was named "Central High," while the high school for girls was named "Girls High." Id. at 881.

93. The special service system is characterized by smaller vehicles, "demand-responsive service, point of origin to point of destination service, and flexible routing and scheduling." 49 C.F.R. $\$ 27.5$ (1987).

94. DOT Rules, supra note 90, at 19,004. Proponents of the "special service" option stress the advantages of individualized service. Opponents emphasize several disadvantages: "special service" requires planning trips ahead of time because of a waiting period of up to 24 hours, see 49 C.F.R. $\S$ 27.95(b)(2) (1987); it precludes travel with nondisabled friends because eligibility is restricted to those unable to use the regular bus service, see 49 C.F.R. $\S 27.95$ (b)(1) (1987); and people may be stigmatized by being relegated to a separate system. 
cided that these concerns were outweighed by other interests, such as the value of local decisionmaking. ${ }^{95}$ Freedom from government regulation, however, may mean the freedom to act based on prejudice, and should not necessarily be treated as a legitimate interest to be balanced against interests in equality. ${ }^{96}$

The rules establish minimum service requirements governing fares, area and time of service, restrictions on eligibility and trip purpose, and waiting periods. ${ }^{97}$ Under these rules, service for people with disabilities must generally be "comparable" to service for nondisabled people, but can still be somewhat inferior. ${ }^{98}$

The rules balance these service requirements against the transit agencies' interests in minimizing cost. A cost cap provision exempts a transit agency from the required minimum levels of accessible service if it spends three percent of its annual operating budget on service for people with disabilities. ${ }^{99}$ DOT claims that this cost limit on required accommodations will prevent undue burdens that are beyond its authority to impose under section 504, particularly in light of $A P T A$, while still requiring improved service for people with disabilities. ${ }^{100}$

A federal district court recently decided, however, that this cost cap is unlawful. ${ }^{101}$ The court held that the cost limit nullified Congress's mandate for minimum standards ${ }^{102}$ by allowing transit agencies to avoid complying with the service requirements. ${ }^{103}$ This decision is being appealed, and during the appeal all parts of the 1986 rules remain in effect.

The cost cap demonstrates able-bodied bias: The costs of the existing system are normal and acceptable, while the costs incurred by meeting the needs of people with disabilities are different and burdensome, subject to a three percent cost limit. The cost limit provision fails to question costs of meeting the needs of nondisabled people, even though these costs may be equally, or more, burdensome. For example, seats in buses often cost more

95. See DOT Rules, supra note 90, at 19,004; see also Americans Disabled for Accessible Pub. Transp. (ADAPT) v. Dole, 676 F. Supp. 635 (E.D. Pa. 1988) (rejecting challenge to the special service option).

96. See Memorandum for Plaintiff' ADAPT in Support of their Motion for Summary Judgment at 80-81, ADAPT v. Dole, 676 F. Supp. 635 (E.D. Pa. 1988) (comparing "local option" for separate bus service to "freedom of choice" school desegregation plan struck down in race discrimination case).

97. 49 C.F.R. § 27.95 (1987).

98. For example, under the service requirements, "special service" fares of $\$ 1.50$ would likely be comparable to $\$ .80$ bus fares. 49 C.F.R. $\$ 27$ app. at 225 (1987). Accessible bus systems must provide service at "reasonable intervals" throughout the same days and hours as service for the "general public," but all buses need not be accessible. Id. at 226 .

99. 49 C.F.R. § 27.97 (1987).

100. See DOT Rules, supra note 90 , at $18,998,19,011-13$.

101. ADAPT v. Dole, 676 F. Supp. 635 (E.D. Pa. 1988).

102. See 49 U.S.C. app. $\S 1612$ (c) (1982); supra text accompanying note 83 .

103. See ADAPT v. Dole, 676 F. Supp. at $641-42$. In addition, the court found the cost cap arbitrary because DOT studies showed small cities choosing the special service option would rarely be able to meet the service criteria within the spending limit. Id. at 642 . 
than wheelchair securement devices. ${ }^{104}$ Moreover, the cost cap perpetuates past prejudice. Those transit agencies that have made few efforts toward accessible transit are most likely to incur the greatest expenses in improving access and thus most likely to meet the cost cap. ${ }^{105}$

The 1986 rules have a biased view of benefits as well as costs. Modifications designed to make buses accessible to people with disabilities may benefit all riders in ways that offset the costs. For example, in the 1970's DOT advocated the accessible low-floored Transbus as a design that would benefit all riders. ${ }^{106}$ Low floors and ramps instead of stairs would be better for many people, such as small children, elderly people, and parents with babies in strollers. In spite of these potential benefits, however, the 1986 rules generally treat costs of accommodations as burdensome. ${ }^{107}$

In sum, the DOT regulations, both past and present, embody the biased view that making public transit accessible to people with disabilities is an act of charity to a special, separate group whose needs are often unmanageable. Instead, accessible public transit should be considered an ordinary service that benefits the public.

\section{Reaffirming the Disparate Impact Model}

Subtle and pervasive able-bodied bias, not simply physical difference, leads to the socioeconomic disadvantages that attach to physical disability. Thinking about the problem as an issue of eliminating prejudice rather than simply accommodating difference would improve disability discrimination doctrine. ${ }^{108}$

Disability discrimination doctrine should confront the prejudice that makes the "differences" related to disability seem like abnormal, separate problems that are necessarily disadvantageous. Instead of approving special, segregated services, courts and policymakers should follow the disparate impact model, which generally requires that unjustified policies with harmful effects be changed as a whole, rather than remedied through sep-

104. Wheelchair securement devices commonly used in public buses cost approximately \$85. Telephone interview with Peter Zarba, J. Bussani, Inc.-Adaptive Driving Equipment (Jan. 18, 1988). Two-passenger seats used by one bus company cost roughly $\$ 575$. Telephone interview with Jim Miller, Parts Dep't, Flxible Corp. (Feb. 8, 1988).

105. See Note, Section 504 Transportation Regulations: Molding Civil Rights Legislation to Meet the Realities of Economic Constraints, 26 WASHBURN L.J. 558, 581 (1987).

106. See R. Katzmann, supra note 13, at 133. The Transbus design had wide doors and low floors that could be fitted with ramps to provide wheelchair access. Id. at 133-34.

107. The rules do recognize to some extent that separately counting costs of service to people with disabilities can be problematic. Calculations of cost may not include "the cost of items that generally improve the [transit system's] entire service to the public." 49 C.F.R. $\$ 27$ app. at 229-30 (1987).

108. In its most recent decision on $\S 504$, School Bd. v. Arline, 107 S. Ct. 1123 (1987), the Supreme Court appropriately focused on the importance of recognizing and eliminating prejudice in its decision that a person with tuberculosis is covered under $\S 504$ 's definition of "handicap." The Court has not adequately extended this recognition of prejudice to other issues, however, such as the extent of accommodations required under $\$ 504$. 
arate policies targeted at the adversely affected groups. ${ }^{109}$ Consistent with the disparate impact model's treatment of race and sex discrimination, ${ }^{110}$ the law should adopt a presumption that a program's adverse effects on people with disabilities are discriminatory. Disability discrimination doctrine should not assume that public programs can normally be designed to be more effective for nondisabled people than for people with disabilities as long as programs make some accommodations or do not completely exclude people with disabilities. ${ }^{111}$

Presuming that programs should be equally effective for both people with disabilities and able-bodied people does not necessarily preclude consideration of competing interests such as cost savings. ${ }^{112}$ Simply balancing concerns such as cost against the interest of people with disabilities in access to public programs, ${ }^{113}$ however, is inappropriate because these concerns are likely to incorporate able-bodied biases. ${ }^{114}$ Instead, the disparate impact model's presumption of equal effects should be used to encourage careful scrutiny of justifications for adverse effects to ferret out bias. ${ }^{115}$

Several requirements would minimize subtle prejudice in assessing the costs of making programs equally effective for people with disabilities. ${ }^{116}$ First, courts and policymakers should carefully examine actual evidence of costs of making programs fully accessible. Estimates of the cost of provid-

109. See Williams, supra note 52, at 364-65.

110. See supra note 22 and accompanying text.

111. See supra notes 30, 84-87 and accompanying text; Alexander v. Choate, 469 U.S. 287, 298-99 (1985) (refusing to apply disparate impact doctrine to some situations of adverse impacts under $\$ 504)$. The variety in the types and severity of disabilities can complicate consideration of adverse affects. Nevertheless, if consideration of needs of people with disabilities became normal and not exceptional, it is likely that this process would generally be routine, not burdensome.

112. Despite general agreement among courts and commentators that $\S 504$ allows costs to be taken into account, there is conflict over when, if ever, cost concerns justify inaccessible or ineffective programs. See Cook, The Scope of the Right to Meaningful Access and the Defense of Undue Burdens Under Disability Civil Rights Laws, 20 LoY. L.A.L. REv. 1471 (1987) (cost cannot abrogate meaningful access). This Note does not directly address this issue, but instead simply seeks to suggest ways of minimizing bias when cost is considered.

113. See supra note 31 and accompanying text.

114. Prejudice may distort lawmakers' decisions, for example, by causing them to weigh costs to one group heavily, while devaluing or ignoring costs to groups who are underrepresented in the political process. See J. Er.y, supra note 33, at 153-58; see also Lawrence, The Id, the Ego, and Equal Protection: Reckoning with Unconscious Racism, 39 STAN. L. REv. 317, 347-49 (1987) (unconscious biases cause similar political process distortions).

115. Even though the disparate impact doctrine has resulted in significant gains in race and sex discrimination cases, courts often use disparate innact in a restrictive way that leaves subtle race and gender biases in place. See, e.g., Boyd v. Ozark Air Lines, 568 F.2d 50, 53-54 (8th Cir. 1977) (height requirement for airline pilots that adversely affected women justified because cockpit designed for pilots of that height); Bartholet, Application of Title VII to Jobs in High Places, 95 HARv. L. REv. 945, 967-78 (1982) (courts have often failed to apply strict standard of justification to defenses of practices with disparate effect on women or minorities in upper level jobs); Note, Getting Women Work That Isn't Women's Work: Extending Title VII to Eliminate Gender Bias in the Workplace, 97 YALE L.J. (forthcoming 1988) (courts' current use of disparate impact doctrine fails to remedy many male biases in employment).

116. For an example of a regulation with some requirements for careful scrutiny of justifications for inaccessible transportation, see Maine Human Rights Comm'n, Public accommodations Regulations Relating to Handicap Discrimination in Public Conveyances, Part III-E (1987) ("undue burden" exceptions to accommodation requirement). 
ing access to programs such as public transportation often vary widely, ${ }^{117}$ and in many cases may actually be minimal. ${ }^{118}$ For instance, in one case, the cost of wheelchair-accessible buses was comparable to that of the inaccessible buses the city had bought. ${ }^{119}$

Second, the contribution of past discrimination to current high costs should be considered. Cutbacks in service for able-bodied people may be justified because of past burdens imposed on people with disabilities and because policymakers refused to design programs that would have been accessible in the first instance. ${ }^{120}$ Third, less costly alternatives should be carefully investigated ${ }^{221}$ in consultation with disability rights groups. ${ }^{122}$ Fourth, cost should be treated similarly for both people with disabilities and nondisabled people. ${ }^{123}$ For example, to save costs, agencies should not simply limit service for people with disabilities, but should make cuts which equivalently affect people with disabilities and nondisabled people. ${ }^{124}$

\section{GonClusion}

By incorporating the erroneous perception that the problem is one of addressing "different" needs, disability discrimination law remains confused and only partially successful. A closer look reveals that prejudice against people with disabilities is widespread. This prejudice fosters the perception that the particular needs of people with disabilities are necessarily "different" and disadvantageous. By using strategies from race and sex discrimination doctrine designed to address subtle prejudice and its effects, disability discrimination doctrine can better ensure that federally funded programs are effective for all people, not just those who are ablebodied.

117. See U.S. COMM'N ON Civil Rights, supra note 7, at 79-80. Benefits, such as increased numbers of riders, may offset costs. A study for DOT at one time estimated over $\$ 800$ million in annual benefits to the public from eliminating transportation barriers. OfFICE OF THE SECRETARY, U.S. Dep'T of Transp., Travel Barriers 19 (1970), cited in Reed, Equal Access to Mass Transportation for the Handicapped, 9 TRANSP. L.J. 167, 171 (1977).

118. In a 1987 survey, $75 \%$ of managers said the average cost of employing a person with a disability is about the same as the cost of employing a nondisabled person. Louis Harris \& Assoc., Inc., Study No. 864009, The ICD SuRvey II: Employing Disabled AMERICANS 9 (1987).

119. See Maine Human Rights Comm'n v. City of S. Portland, 508 A.2d 948, 952 \& n.3 (Me. 1986).

120. See supra text accompanying note 105 .

121. In title VII cases, some courts interpret the disparate impact approach to require a search for less harmful alternatives as part of the defendant's burden of justifying a policy that adversely affects a protected group. See Robinson v. Lorillard Corp., 444 F.2d 791, 798 \& n.7 (4th Cir. 1971). This requirement is an appropriate and useful means of reaching subtle bias that often results in lack of concern about possibilities for meeting "different" needs.

122. The 1986 DOT rules take some steps in this direction by requiring public participation in transit agencies' plans. See 49 C.F.R. § 27.83 (1987).

123. In contrast, the 1986 rules separately limit the cost of improving service for people with disabilities. See supra text accompanying notes 99-107.

124. See Wegner, supra note 24 , at 507 (criticizing cost-efficiency defenses where people with disabilities alone bear their own costs of receiving services). 